\title{
The impact of Industrial Policy on Export Diversification: Some Empirical Evidences from Pakistan
}

\author{
Amir Azam \\ Pakistan Institute of Development Economics \\ amirazam_17@pide.edu.pk
}

\begin{abstract}
Export sector is considered as the backbone of any economy. The economy which is efficient and competitive in global market enjoys better export performance otherwise become dependence on foreign goods market. Pakistan being a developing economy faces worse export performance as compare to its past competitors and currently economy faces huge current account deficit. The current study made an attempt to check the relationship between Industrial Policy and export diversification using ARDL approach because of different integration nature of variables under consideration from 1980-2018. The findings of the study suggests that there is strong relationship between industrial Policy instruments and export diversification both in short run and long run and by enhancing strong and visionary Industrial Policies and less relying on imports, the economy can enjoy sufficient growth and diversify its export structure.
\end{abstract}

Keywords. Industrial Policy, Export Diversification, Export Diversification Index, Herfindal Index, Market Penetration

\section{Introduction}

Going back to 1960's and 70's the economy of Pakistan was considered as one of the fastest growing economy not only in South Asia but also in global market (Siddiqui, 2018) and Khan (1998) elaborated that by viewing the history of export performance of Pakistan with other developing economies, the individual performance of Pakistan's export was higher than the overall performance of Philippines, Turkey, Korea and Indonesia in 1960's but soon after we unable to diversify our industrial sector both at market and goods level that bring us as lower as even we can't export half of the lowest exporting goods of the above economies. The increasing trade deficit with passing time exacerbating the anxiety among policy makers because they are of the view that the policies and target of the government towards strategic trade policies in Pakistan are unable to be lateralized and show vulnerable and dismal picture of our export sector (Malik \& Majeed, 2018). Most of Pakistani product market usually linked with only few market i.e. America, China, Afghanistan, UK and Germany that contributes around $60 \%$ in 1960 and $47 \%$ share of total exports in 2018 showing that we are able to diversify our market level only $13 \%$ in more than half century with still very high dependency on same products that we were exporting in 1960's are still our highest contributors in total exports (Mahmood \& Ahmad, 2017). One of the major instrument that government utilize to promote the diversification of goods and market is Industrial Policy. 
From Industrial Policy we mean that the government intervention in Industrial sector through various instruments and channels to stabilize and promote Industrial contribution in the economy. The economy of Pakistan is considered as agrarian economy since independence agriculture contributed the most in both GDP and employment share but after liberalization the agricultural contribution in GDP and employment is falling that is being taken place by service and industrial sector. There has been observed tremendous growth in industrial sector share but the rhythm that was expecting couldn't be achieved because of many reasons found by different researchers i.e. Energy crises, political instability, no friendly business environment in the economy, high tariff rate in the economy, low rate of diversification, less reliance on sophisticated good's export and most importantly the economy always observed power battle between democracy and autocracy and coherence and long term visionary industrial policy in Pakistan always remained a question that need special attention to be answered because the policy shifting or policy changing environment in the economy let the policy to shift and new focus is being displayed that let the economy never to observe a visionary policy. The current study seeks to highlight the empirical relationship between Industrial Policy and Export Diversification. As we know that Industrial Policy itself isn't a variable but consists of different indicators or variables that are used as tool of Industrial Policy and the government bring changes in these tools to promote Industrialization in the economy. Hence the current study is taking import tariff, export subsidy, export rebate, industrial expenditures, Research and Development expenditures and Economic processing zone's as instruments of Industrial Policy while Herfindal Index is use to show that how much our economy is open for international market and Export Diversification Index is use to elaborate the diversification performance in the economy. The study relied descriptive and empirical base analysis because through descriptive analysis its being tried that how the instruments of industrial policy of Pakistan are different from that of neighboring and emerging economies while ARDL model is used to check the association between Industrial Policy and export diversification.

\section{Previous Studies}

The past studies show mixed up relationship between Industrial Policy and Export Diversification, most of the studies have taken the instruments of industrial policy separately rather than as instruments of Industrial Policy only few studies have discussed the instruments of industrial policy while comparing its impact on different dependent variables. About export diversification and its determinants Agosin et al., (2011) argued that trade openness, human capital, remoteness, terms of trade, domestic credit, exchange rate volatility and overvaluation have been observed as focused determinants of diversification around the world with a large set of data of 79 countreis from 1962-2000 while Ferrantino (1979) analyzed successful experenice of Chillie and concluded that real depreciation of exchange rate with reforms in trade have positive effect on export diversification and Melitz (2003) argued that export diversification is induces from trade liberalization that cause to increase the exporters in both goods and producers promoting export oppurtunities with attaining better quality. Ferdous \& Binti (2011) discussed the determinants of export diversification in East Asian Economies, where they concluded that official exchange rate and GDP are inversely related because when GDP increases the economy move to sophistication rather than diversification while increase in official exchange rate make it lower prices that cause the producers to face extra cost in home country gaining low profits, while trade intensity and tariff rate in protected economy cause inverse relationship with herfindal index which measure diversification intensity i.e. higher the Herfindal Index lower will be diversification level and vice versa. Dioquino \& Abouellial (2015) argued that in South Korean case, Macroeconomic stability indictor play negative role 
in diversification while trade openness, official exchange rate, governemnt expanditures and capital formation have significant positive role with diversification even at $1 \%$ level.

Highlighting the role of Industrial Policy, Gyroff (2014) stated that industrial policy is "the tool of existing government to achieve her certain ojectives usually consisting of three basic instruments like regulatory which is use to manage framework conditions through regulations, second is financial indicator that is applying limit direct subsidy type , financial support, industrial investment both private and public sector for the promotion of industrial sectors according to predefined targets and finally focusing on their distribution importance with rest of world. Zalk (2014) argued that basically government promote industrial policy to promote the export pefromance and in intial phase economy move to diversify in global market and phase competition, that promote its competitiveness and when it diversified and competitive than it move towards sophistication. By relating Industrial Policy with export diversification (Agosin, Alvarez, \& Ortega, 2011) stated that economies will well equiped industrial sector under strong promoting industrial policies easily swept out the competitiors in international market, because the industrial policy make the domestic economy to stand on its foot to compete with global market. (Kozo \& Tetsuji, 2013) proped that long term industrial policy is key instruments can be used to boostup diversification both at goods and market level. Analyzing relationship between Economic development and industrial policy, Kharel, (2014) studied Nepal using OLS taking Industrial registration as the dependent variable while Openness Index as Independent variable for post and pre liberalization period and also combined period of time from 1973 to 2010, concluded that before the liberalization the impact of independent variables have been observed showing positive results while in case of Post liberalization it has been observed inverse relationship between dependent and independent variables, so the further policies have to be designed to meet the rising issues and challenges.

The above discussed previous studies shed light on export diversification and industrial policy and mutual association with each other. Since there are certain indicators and instruments that are use to the export diversification and industrial policy. The current study used Herfindal Index and export diversification index to denote the export diversification while import tariff, export subsidy, export rebate, industrial expenditures and $r \& d$ expenditures as instruments of industrial policy and empirically analyzed using ECM and ARDL approaches that will be an addition in literature which is the lack as my best knowledge.

\section{Research Methodology}

Data

The analysis of export diversification and its indicators require suitable and carefeul measurement. Certain indices and indicators are use to explain the phenomenon based on degree of diversification and export concentration (Malik \& Majeed, 2018) which are based on strenghts, weakness and properties which are expressed in absolute and relative based on heterogentity. The absolute measure comprises Herfindal Hirschman Index (Akbar et al., 2000) , Entropy Inex , Hirschman Gini Absolute Index (Agosin, Alvarez, \& Ortega, 2011) while relative measure comprises Theil Index and Relative Gini Index, concentration index, penetration index with trade concentration ratios uses as concentration measures (Mubeen \& Ahmad, 2016). Since in developing economies the availbility of data is one of the major issue and being developing economy Pakistan also have some issues regarded to data, so the current study is focusing Gini Hirschman Index as absolute measure while Concentration index as relative measure. For Gini Hirschman Index the data is obtained from the study of (Mubeen \& Ahmad, 2016) who have found the index for Pakistan from 1980-2015, the remaining 4 years 
data will be generated by using the methods applied by the authors while Concentration index data is being obtained from World Trade Organization's data base.

Since Industrial Policy itself isn't a quantitative variable rather it comprises different tools and instruments that are use as instruments of industrial policy both qualitative and quantitative. (Weiss, 2015) propped that usually economies uses Tariff rate, governemnt expenditurs on industrial sectors, benefits to producers i.e. rebate, subsidies etc, innovation expenditurs, export charges, currency depreciation benefits as quantitative instruments while free good list, list of prohabited exports and imports, quota, legal restrictions etc as qualitative approach and instruments to promote the export from industrial sector. The current study focuses only on the quantitative measures where only 5 instruments i.e. Import tariff, export subsidy, industrial expenditures, r\&d expenditures and export rebate is being focused by considering other insturments constant. Industrial policy in the analysis is being analyzed in two ways, in first part only the instruments of industrial policy is being regressed with diversification to check the individual relationship with dependent variable while in secod section through Principal Component Analysis (PCA) the instruments of Industrial Policy is being replaced with Industrial Policy Index and regressed with control set of variables. The control variables have been taken from the studies of (Mahmood \& Ahmad, 2017; Siddiqui, 2018; Malik \& Majeed, 2018) who used them while determining the determinants of export diversification. By focusing the literature on diversification and industrial policy, foreign direct investment, exchange rate, GDP, Domestic Credit, Terms of Trade and gross capital formation are being chosen as set of control variables.

$$
\text { E.D }=f(\text { I.P, Xt) where } \mathrm{t}=1980 \ldots \ldots . .2018
$$

E.D show export divesification, I.P is Industrial Policy Instruments and Xt show set of control variables.

\section{Methodology}

Since we are dealing with time series data, and time series data comprises different trend and shocks that let the variables to behave non stationary i.e. mean and variance do not remain constant, Philips (1986) stated that in the presence of non stationary the simple regression results are misleading but the presence of co-integration among focused variable can give plausible and meaningful relationship. To check the problem of unit root in our time series we are relying on Augmented Dickey Fuller (ADF) test because it is more powerful and have relevant estimations related to trends other changes. The equation representation of ADF test is given as below.

$$
\Delta \mathrm{Yt}=\alpha+\beta t+\delta Z t-1+\sum_{i=1}^{p} \theta \Delta \mathrm{Zt}-1+\varepsilon \mathrm{t}
$$

$\mathrm{H}_{\mathrm{o}}$ : There is unit root problem

$\mathrm{H}_{1}$ : There is no unit root problem

While checking the problem of unit root the null hypothesis is being checked at $5 \%$ significance level where the inclusion of trend and intercept is being decided on the basis of nature of variable i.e. intercept being included for normal/ level type variable while for ratio variables the intercept is being excluded, and for trend the graphical representation is taken as base of decision in the presence of trend in the graph there has been both intercept and trend excluded and the test being run without trend and intercept while in the absence of trend, its being included during unit root analysis. Since the variable showed irregular nature of 
integration order and such case ARDL test that follow bounding test procedure is applied to check the co integration among the variables while ECM parameter of checking speed of adjustment and long run relationship the ECM findings are also been taken under consideration with Cumulative Sum of recursive residual test is used for stability of the model.

\section{Data Sources}

The current study considered the export diversification index and concentration index as dependent variable while instruments of industrial policy i.e. import tariff, export subsidy, export rebate, industrial expenditures and $r \& d$ expenditures with a set of control variables i.e. foreign direct investment, exchange rate, GDP, Domestic Credit, Terms of Trade and gross capital formation are been taken as independent variables. The export diversification index have been taken from the study of (Mubeen \& Ahmad, 2016) while Concentration index is from World Integrated Trade Solution (WITS) while rest of the variables have been taken from World Development Indicators (WDI) and International Financial System (IFS).

\section{Data Analysis}

Descriptive Analysis

The focus of the study is checking the relationship between Industrial policy and export diversification. Since industrial policy deals through different instruments and without comparing the industrial policy instruments with other region we can't predict that how open or close industrial policies have been adopted by economies. The below table give a quick overview of descriptive statistics behavior of industrial policy instruments.

Table 1: Descriptive Analysis of Industrial Policy Instruments of Pakistan

\begin{tabular}{lccccc}
\hline & $\begin{array}{c}\text { Industrial } \\
\text { Expenditures } \\
\text { \% of GNE }\end{array}$ & $\begin{array}{c}\text { Export } \\
\text { Subsidy(\% } \\
\text { of GNE) }\end{array}$ & $\begin{array}{c}\text { R\&D (\% of } \\
\text { GNE) }\end{array}$ & $\begin{array}{c}\text { Import Tariff } \\
\text { Rate (\%) }\end{array}$ & $\begin{array}{c}\text { Rebates }(\% \\
\text { of GNE) }\end{array}$ \\
\hline Mean & 20.13574 & 7.365685 & 0.229078 & 28.51351 & 1.088052 \\
Median & 20.05136 & 7.272872 & 0.128280 & 14.97000 & 1.227671 \\
Maximum & 25.38367 & 10.86837 & 0.990000 & 77.30000 & 2.859420 \\
Minimum & 17.06846 & 2.396278 & 0.080000 & 9.120000 & 0.148716 \\
Std. Dev. & 0.914461 & 1.501497 & 0.194489 & 1.179393 & 0.654980 \\
Skewness & 0.089735 & -0.032315 & 0.055605 & 0.008961 & 0.075835 \\
Kurtosis & 3.219556 & 2.871278 & 2.698343 & 3.241320 & 2.806596 \\
& & & & & \\
\hline Jarque-Bera & 3.008010 & 2.645109 & 2.928720 & 4.928720 & 0.928720 \\
Probability & 0.222238 & 0.266454 & 0.328537 & 0.128537 & 0.628537 \\
& & & & & \\
Sum & 745.0224 & 272.5304 & 8.475880 & 1055.000 & 40.25794 \\
Sum Sq. Dev. & 131.9457 & 225.2695 & 1.361738 & 16148.40 & 15.44397 \\
Observations & 39 & 39 & & & 3 \\
\hline
\end{tabular}

The above table give short overview of Industrial policy instruments descriptive behavior in Pakistan from 1980-2018. We can see that on average the Industrial expenditures have been remained $20.13 \%$ of total government national expenditures with highest share of $25 \%$ in 2004 followed by minimum share in 2016, showing that the average share of industrial expenditure in the economy is fluctuating with respect to time, when we carefully analyze the 
average share of Industrial expenditure of competing Asian Economies, the fact shows that there has been on average $15 \%, 17 \%, 12.3 \%$ and $9 \%$ growth have been made by Bangladesh, India, Sri Lanka and Pakistan respectively. So we can say that on average the competing Asian economies have made more investment on industrial sector as compare to Pakistan. Export Subsidy is considered as the major weakness of developing economies (Haq \& Kemal, 2007) because most of the economies suffer because of international competition and in the presence of global competition to make the domestic producers able to survive government support these infant industries through provision of subsidies and rebates on raw materials or energy inputs or borrowing from national banks etc. to minimize the cost of production and support to promote the business sectors (Abbas, 2015). From the descriptive statistics results of the industrial policy instruments we can see that the Pakistan economy provide $7.3 \%$ and $1.08 \%$ on average subsidies and rebate to the industrial sector while that in case of Bangladesh, Sri Lanka and Indian have remained $9.21 \% 5.45 \%, 6.23 \% \& 2.01 \%, 1.32 \%, 0.021 \%$ respectively in the above mentioned variables and economies (WITS, 2018). We can say as compare to other competing Asian Economies Pakistan is more curious about its industrial sector and pay good sum of export rebate and export subsidies that let enjoy the domestic economies to enjoy well enough profit but (Haq \& Kemal, The Impact of Export Subsidy on Pakiastan's Export, 2007) argued that without any significant relationship or impact of export subsidy and rebate, Pakistan is paying huge sum on Industrial sector that involve in export side.

Since Structural Adjustment Program (1988) most of the international economies are playing role to become liberalize i.e. more open for international trade by lowering the trade barriers and Import Tariff Rate is considered as one of the key trade barrier in free trade (Das, 2002). When we analyze the historical data of South Asian Economies we can see that mostly the economies were highly protected in 80's but after the adoption of Structural Adjustment Program they have cut the import tariff rate at huge level on average they cut the tariff rate from $90 \%$ in 1980 to $10 \%$ in 2017 , that boosted up not only the imports of the goods and services but the export have also risen tremendously. The below figure give a quick look of the average decrease in import tariff rate in the South Asian Economies.

Figure 1: Average Tariff Decline in South Asian Economies

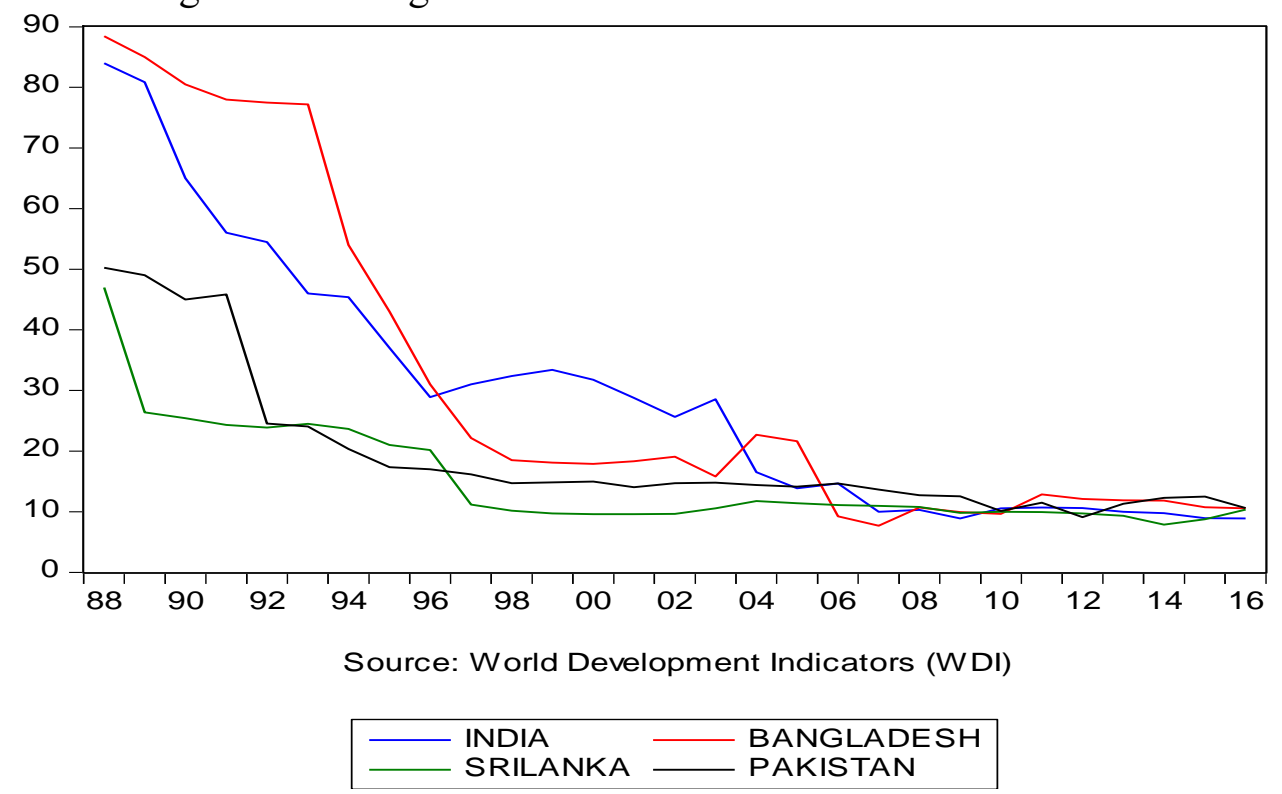


The above figure shows that Bangladesh showed more quick response to cut off its tariff rate that was $92 \%$ in 1980 's brought down to $18 \%$ in 1999 that further been decreased to $9.5 \%$ in 2017. Das (2002) argued that one of the basic reason behind the success of Bangladesh in promoting its market and good diversification is because of Bangladesh principal policy of export promotion and market openness that welcomed huge capital inflow that nourished the production sector specially the apparels and garment industry while Pakistan was owing good share of garment industry in global market that being affected and Bangladesh stood in front as competitor in global market that cut down Pakistan's share.

To improve the level of production and quality of production it is very important to find out the best and suitable methods that can bring cost down and production high. The developed nations of the world are mostly relying on Research and Development. Research and Development expenditures are consider as the important part of government expenditures and government fixed a specific amount or share from its total expenditures for Research and Development. South Asian economies also keep a lump sum amount of their annual expenditures on research and development. From table 1, we can see that on average Pakistan is spending $0.229 \%$ on R\&D which is very low when we compare it with India and Sri Lanka because they are spending $0.8 \%$ and $0.23 \%$. From the given graphs we can see on average South Asian economies are spending how much on R\&D.

Figure 2: R\&D Expenditures made by Competing Asian Economies

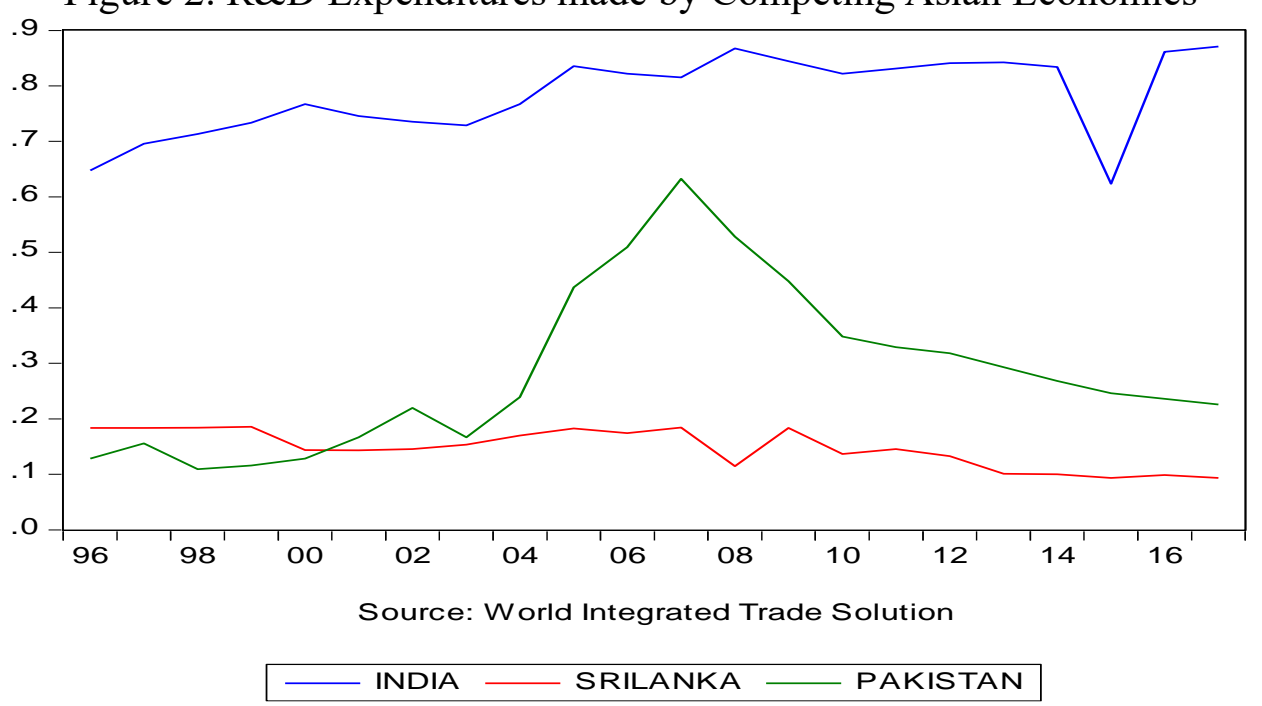

The results indicates that during Musharaf's regime R\&D section saw golden period where on average $0.42 \%$ of total expenditure was made on R\&D but later in the era of democracy there is being fall in R\&D expenditures. (WITS, 2018) results indicates that the economy of Pakistan as compare to other Asian economy is more open and well diversified in terms of market because the average Herfindal Index of the economy is 0.064 while 0.0489 , 0.0917 and 0.1045 in India, Bangladesh and Sri Lanka respectively that denotes only India is ahead from Pakistan while Bangladesh and Sri Lanka are still far out from Pakistan and India. But the market penetration (availability of consumer's willingness to purchase the goods) in Pakistani product is very low which is 7.33 while India, Bangladesh and Sri Lanka have 24.72, 5.17 and 5.11 showing that still we have enough space to reach maximum number of consumers. About Pakistan's market penetration and Herfindal Index (Hussain, 2018) argued that the quality and standard of Pakistani goods don't have the standard to compete in international market, due to that being have high capacity of market penetration still we are unable to gain 
the attention from international consumers. The below table highlights a quick overview of the Herfindal index and market panetration of South Asian Economies from 2003-2018.

Table 2: Herfindal Index and Market Penetration of South Asian Economies

\begin{tabular}{lccllllll}
\hline & PAK & PAK & IND & IND & BAN & BAN & SRI & SRI \\
& HI & MP & HI & MP & HI & MP & HI & MP \\
\hline Mean & 0.063 & 7.378 & 0.048 & 24.928 & 0.0905 & 5.248 & 0.102 & 5.152 \\
Median & 0.060 & 7.370 & 0.046 & 25.687 & 0.0920 & 5.171 & 0.095 & 5.140 \\
Maximum & 0.090 & 8.140 & 0.064 & 28.143 & 0.121 & 6.487 & 0.157 & 5.684 \\
Minimum & 0.050 & 6.180 & 0.040 & 18.021 & 0.070 & 3.912 & 0.074 & 4.233 \\
Std. Dev. & 0.015 & 0.549 & 0.071 & 3.1021 & 0.018 & 0.804 & 0.026 & 0.446 \\
Skewness & 0.793 & -0.420 & 0.8185 & -0.940 & 0.242 & 0.098 & 0.775 & -0.364 \\
Kurtosis & 2.198 & 2.608 & 2.608 & 2.830 & 1.647 & 1.951 & 2.405 & 2.602 \\
Observations & 17 & 17 & 17 & 17 & 17 & 17 & 17 & 17 \\
\hline
\end{tabular}

Note: HHI denotes Herfindal Index and MP denotes Market Penetration

From the given above table we can see that average performance of Pakistan economy in international trade openness market is well enough open as compare to Sri Lanka and Bangladesh but we are still behind from that of India, while in Market Penetration level the economy is far is still have potentials to reach maximum numbers of available market consumers.

\section{Unit Root Analysis}

The below table give an overview of the unit root analysis to see the order of integration of variables to avoid the problem of spurious regression. The inclusion and exclusion of trend and intercept, both or none being decided on the basis of variables nature i.e. intercept being included to the level variables while for ratio variables there is being excluded the intercept while for trend the nature of graph being observed i.e. in the presence of trend its being excluded while in linear graphical representation its being included in the model.

Table 3: Unit Root Analysis of Industrial Policy Instruments and Export Diversification Indices

\begin{tabular}{lllll}
\hline \multicolumn{5}{c}{ ADF } \\
Dependent & Difference & $\begin{array}{l}\text { without } \\
\text { Trend }\end{array}$ & $\begin{array}{l}\text { With } \\
\text { Trend }\end{array}$ & \\
\hline Herfindal Index & Level & -0.624 & -1.968 & $\mathrm{I}(1)$ \\
& First Difference & -2.962 & -5.478 & \\
Export & Level & -1.664 & -6.4285 & $\mathrm{I}(0)$ \\
Diversification & First Difference & -2.002 & -3.221 & \\
\hline Independent & & & & \\
Variables & & & & \\
\hline Import Tariff & Level & -2.983 & -1.46 & $\mathrm{I}(1)$ \\
& First Difference & -6.244 & -7.254 & \\
Export Subsidy & Level & -0.972 & -2.17 & $\mathrm{I}(0)$ \\
& First Difference & -6.888 & -6.762 & \\
& Level & -2.001 & -1.923 & $\mathrm{I}(1)$ \\
\hline
\end{tabular}




\begin{tabular}{lllll}
\hline Industrial & First Difference & -6.213 & -6.762 & \\
Expenditures & & & & \\
Export Rebate & Level & -1.267 & -3.561 & $\mathrm{I}(1)$ \\
& First Difference & -8.641 & -8.638 &
\end{tabular}

From the above table of unit root analysis we can see that the concerned variables are different ordered and in the presence of different order of integration we can't rely on simple regression model. So we are using ARDL approach because it is use to capture the stochastic and deterministic trends that cause or change the order of integration of variables basically using the optimal lag length of both dependent and independent variables.

\section{ARDL Estimations}

Since the focused variables are different ordered integrated, therefore we preferred ARDL approach that not only show the Cointegration among variables but also give long run static relationship. The given below table show the findings of ARDL for a period from 19802018.

Table 4: ARDL Estimates of Relationship between Industrial Policy and Export Diversification in Pakistan

\begin{tabular}{lllll}
\hline & Coefficient & Std.Error & t-value & t-prob \\
\hline EDIV_1 & $0.443247^{*}$ & 0.1329 & 3.33 & 0.0794 \\
Constant & $6.87282^{*}$ & 2.63 & 2.61 & 0.0820 \\
DC & $0.788191^{* *}$ & 0.1043 & 7.56 & 0.0171 \\
EXPGDP & $0.21969^{*}$ & 0.082 & 2.679 & 0.0830 \\
EXPGDP_1 & -0.38784 & 0.1936 & -2.032 & 0.1830 \\
EXPGDP_2 & $0.528603^{* *}$ & 0.1249 & 4.23 & 0.0515 \\
EXPGDP_3 & $-0.62408^{* *}$ & 0.1335 & -4.67 & 0.0429 \\
GCF & $0.817154^{* * *}$ & 0.0954 & 8.56 & 0.0011 \\
TO & 0.53337 & 0.211 & 2.52 & 0.3668 \\
EHT & 0.132322 & 0.4377 & 0.302 & 0.7909 \\
EHT_1 & $1.48273^{* *}$ & 0.4282 & 3.462 & 0.0780 \\
MSE & 2.38005 & 1.833 & 1.298 & 0.4893 \\
MSE_1 & $-.609 *$ & 0.064 & -2.07 & 0.0820 \\
MSE_3 & $.6833^{*}$ & .0563 & 3.42 & 0.0760 \\
IP & $0.18306^{*}$ & 0.0903 & 2.027 & 0.0850 \\
IP_1 & $0.140581 *$ & 0.0484 & 2.904 & 0.0780 \\
\hline sigma & 0.244315 & RSS & \multicolumn{2}{c}{0.119380054} \\
R^2 & 0.999449 & F(31,2) & \multicolumn{2}{c}{$117[0.009]^{* *}$} \\
Adj.R^2 & 0.990908 & log-likelihood 47.8368 \\
mean(EDIV) & & \multicolumn{2}{c}{47.8608} \\
\hline
\end{tabular}

Note: $(*, * * * * *$, denotes significant at $10 \%, 5 \%$ and $1 \%$ )

The above table shows the findings of ARDL estimates of relationship between industrial policy and export diversification with different control variables. From the above table we can see that lag of export diversification, first lag of export to GDP, Lag of Manufacturing share in export, Industrial Policy and lag of industrial policy give significant 
results at 10\% while second and third lags of export to GDP, Domestic credit and lag of Export of High Technology give significant results at 5\% and Gross Capital Formation give significant result with export diversification at $1 \%$. The significant variables show positive relationship with export diversification with time series features of $\mathrm{r}^{2}$ showing $98.9 \%$ variations in dependent variable is caused by independent variables while F-statistics confirms the significance of model.

From the findings of relationship between export diversification index and Industrial Policy with other set of control variables show that when there is significant industrial policy adopted than one unit increase in the strength of Industrial policy will cause to increase the export diversification index by 0.183 units with a significant level of $10 \%$. It is because strengthening industrial policy means opening more chances of competition among producers and to get survive and promote business culture. Therefore we can say that strong and long term visionary policy can promote export diversification index. (Haq \& Kemal, The Impact of Export Subsidy on Pakiastan's Export, 2007) argued that one of the main reasons why Pakistan failed to diversify in international market is lack of long term visionary industrial policy while (Siddiqui, 2018) propped that newly industrialized East Asian economies have experienced long term and diversifying policy which in Pakistan experienced lack. In Pakistan industrial policy have been evolving on new line and started grappling with created problems in the early 80 's where the statement of policies of various issues have order to allay apprehensions and doubts on various issues and to integrate various policy measures that made Pakistan to design industrial policies to meet the rising issues or changes (G.o.P, 1989). The current findings of the study confirm Cointegration among industrial Policy and export diversification index. Hence to promote export diversification, industrial policy can be use as major tool. The other control variables show that domestic credit, export to GDP ratio, and lag of export of high technology give positive and significant relation with export diversification at $5 \%$ while Manufacturing share in export, show positive relationship at $10 \%$ and gross capital formation show positive relationship at $1 \%$ while trade openness, export of high technology and manufactured share in export give positive but insignificant results. Zalk (2014) in his study concluded that since only textile, leather and rice contributes more than $57 \%$ of our total exports with least share of manufactured goods and technological goods, therefore they are playing least role in export diversification index, that's why they are giving insignificant relation with diversification index.

The below table show the findings of ARDL showing the relationship between industrial policy and export diversification by taking Market Penetration as indicator of export diversification.

Table 5: ARDL Estimates of Relationship between Industrial Policy and Market Penetration in Pakistan

\begin{tabular}{lllll}
\hline & Coefficient & Std. Error & t-value & t- prob \\
MP_1 & 0.891829 & 0.334 & 2.67 & 0.0143 \\
Constant & 2.09265 & 0.678 & 3.086504 & 0.4432 \\
PCA & 0.209982 & 0.0989 & 2.123175 & 0.3483 \\
PCA_1 & 0.006676 & 0.02148 & 2.674388 & 0.759 \\
MSE & 0.557075 & 0.2083 & 1.36 & 0.1869 \\
MSE_1 & -0.20606 & 0.0896 & -2.29978 & 0.6957 \\
EHT & 0.003641 & 0.15033 & 0.0723 & 0.943 \\
EHT_1 & 0.002086 & 0.03653 & 0.0571 & 0.955 \\
\hline
\end{tabular}




\section{(7) TECHNIUM

\begin{tabular}{lllll}
\hline TO & 0.936111 & 0.3192 & 2.932679 & 0.1455 \\
TO_1 & -0.71499 & 0.2838 & -2.51936 & 0.4276 \\
GCF & -0.84492 & 0.3096 & -2.73 & 0.0126 \\
GCF_1 & 0.695903 & 0.2779 & 2.504149 & 0.0206 \\
EXPGDP & -0.02466 & 0.00786 & -3.13752 & 0.1819 \\
EXPGDP_1 & 0.081026 & 0.01556 & 5.207352 & 0.608 \\
DC & -0.00775 & 0.006542 & -1.18508 & 0.9068 \\
DC_1 & 0.034124 & 0.01022 & 3.338953 & 0.7418 \\
\hline sigma & 0.054084 & F(15,21) & 38.42 & {$[0.000]^{* *}$} \\
$\mathrm{R}^{\wedge} 2$ & 0.964845 & log- & 65.9149 & \\
& & likelihood & & \\
Adj.R^2 & 0.959735 & No of Obs & 37 & \\
\hline
\end{tabular}

The above table show the relationship between Industrial Policy and Market Penetration in Pakistan where Market Penetration show the available customers willingness to purchase the commodities available for them to purchase and industrial policy been taken from PCA by combining five different instruments i.e. import tariff, export subsidy, industrial expenditures, export rebates and r\&d expenditures while domestic credit, export to GDP ratio, manufacturing share in export, gross capital formation, Trade openness and Export of high technologies. We can see that Industrial policy and lag of manufacturing share in export are significant at $10 \%$, while lag of industrial Policy, trade openness, lag of trade openness, lag of market penetration, gross capital formation are significant at 5\% and finally export to GDP and lag of domestic credit are significant at $1 \%$. The result of $\mathrm{r}^{2}$ show that $96 \%$ variations in dependent variable is because of variations in independent variables and the value of f-statistics confirm the significance of model.

Usually Market penetration is associated with the numbers of customers who are willing to purchase the available commodities. When we compare the market penetration of Pakistan with different competing South Asian Economies we can see that we are still far behind than the competitors because the market penetration of India is 27.8, Bangladesh have 6.9, while Sri Lanka have market Penetration of 5.6 and Pakistan have average market penetration from 20032018 is 5.98 (WITS, 2018). The findings of the study suggest that there is strong positive relationship between industrial policy and market penetration. Means strong and healthy industrial policy can boost market penetration by 0.20 units because it increases the benefits and fair business environment that let the producers to cope with international market and international competitors. (Hussain, 2018) Argued that since liberalization we faced different social and economical issues that never let the economy to perform in stable position and lack of industrial policy is one of the major weaknesses of Industrial sector. Hence we can say that long term industrial policy can play positive and significant role in the promotion of market penetration. The set of control variables show except share of export of high technology, lag of export of high technology, manufacturing share in export and domestic credit give insignificant relationship with market penetration. Since we are dealing that how much customers are available to purchase the home country's product and Pakistan's economy have least contribution of Manufactured goods with few item of high technological goods and that have tiny contribution in export sector. Therefore we can say that due to tiny part share in total export the relationship of export of high technology and manufacturing share in export give insignificant relationship with market penetration. 


\section{Conclusion and policy recommendations}

From Industrial Policy we mean that the government intervention in Industrial sector through various instruments and channels to stabilize and promote Industrial contribution in the economy. The past studies show mixed up relationship between Industrial Policy and Export Diversification, most of the studies have taken the instruments of industrial policy separately rather than as instruments of Industrial Policy only few studies have discussed the instruments of industrial policy while comparing its impact on different dependent variables. The current study combines the instruments of industrial policy and through Principal Component Analysis, Industrial Policy Index being created and its impact on two broadly measuring dimensions of export diversification is broadly discuss in two major terms like market diversification and products or goods diversification. The current study focused on market diversification and ARDL approach have been applied by taking two major dimensions of export diversification i.e. Diversification Index and Market Penetration. The findings of the study confirm there is strong positive relationship between industrial Policy and export diversification. Usually trade policy and industrial policy are mixed but the current study confirms that trade openness in Pakistan have no significant relationship with both diversification index and market penetration while industrial policy have positive significant relationship with both diversification and market penetration. One of the important factors that need to capture the attention of high authorities is how much we are diversified? When we look towards market we can see we are well diversified because our trade is with more than 200 countries. We are making exports and imports with good number of economies, but the problem is we are exporting only limited number of commodities with international market. Currently in global markets there are trading more than 30 thousands commodities but we are only able to export less than 3 thousands. We are well endowed natural resource economy. Our natural resources, geographical location, environment all support us to rise in international market as trade hub. Therefore we need to diversify our industrial sector promoting new industrial units, encouraging innovations, promoting technical education, creating opportunities to new generations and most importantly strong and visionary policy is also help to boost the diversification.

\section{References}

[1] Abbas, A. (2015). Firm Size, Exchange Rate and Export Performance: A Firm Level Analysis of Pakistan's Manufactruing Sector. Pakistan Journal of Commerce and Social Science (PJCSS) , 9(3), 818-836.

[2] Agosin, M. R., Alvarez, R., \& Ortega, C. B. (2011). Determinants of Export Diversification around the Wrold: 1962-2000. The Wrold Economy, 1-21.

[3] Ahmad, H., \& Hamid, N. (2014). Patterns of Export Diversification: Evidence from Pakistan. The Lahore Journal of Economics , 19, 307-326.

[4] Ahmad, N. (2000). Export Response to Tade Liberalization in Bangladesh:A cointegration Analysis. Applied Economics , 32(8), 1077-1084.

[5] Choudhry, T. T. (2005). Industrial Clusters in Developing Countries: A survey of the Literature. The Lahore Journal of Economics , 15-34.

[6] Das, D. K. (2002). Trade Liberalization and Industrial Productivity; An Assessment of Developing Economies. Indian Council for Research on International Economic Relations .

[7] Dioquino, M. C., \& Abouellial, E. F. (2015). The Determinants of Export Diversification at All Margins Case Study: South Korea. International Journal of Scientific \& Engineering Research , 6 (2), 526-532. 
[8] Fatima, G., \& Rehman, W. u. (2012). A Review of Privatization Policies in Pakistan. Interdisciplinary Journal of Contemporary Research in Business , 3(9), 1017-1032.

[9] FBR. (2002). Federal Tax Receipts (Net) 1992-93 To 2001- 02. Islamabad: Federal Board of Revenue: Revenue Division, Government of Pakistan.

[10] FBR. (1969). The Custom Act, . Islamabad: Government of Pakistan Revenue Division: Federal Board of Revenue.

[11] Ferdous, \& Binti, F. (2011). Pattern and Determinants of Export Diversification in East Asian Economies. International Conference on Social Science and Humanity, 5.

[12] G.o.P, G. o. (1989). The Sixth Five Year Plan (1983-880. Islamabad: Planning Commission, Government of Pakistan.

[13] Haq, N. U., \& Kamal, M. A. (2007). The Impact of Export Subsidy on Pakistan's Export. Pakistan Istitute of Development Economics, Working Paper No: 2007:26 .

[14] Haq, N. U., \& Kemal, M. A. (2007). The Impact of Export Subsidy on Pakiastan's Export. Pakistan Institute of Development Economics; Working Paper 2007; 26 , 2007(26).

[15] Husain, S. A. (1994). History of the State Bank of Pakistan: 1961-77. Karachi: State Bank of Pakistan Press.

[16] Hussain, I. (2018). Pakistan's Economy and Regional Challanges. International Studies , 253-270.

[17] Kozo, K., \& Tetsuji, O. (2013). Effects of Industrial Policy on Productivity:The case of import quota removal during postwar Japan. The Research Institute of Economy, Trade and Industry, 1-35.

[18] Madani, D. (1999). A Review of the Role and Impact of Export processing Zones. The World Bank.

[19] Mahmood, A., \& Ahmad, W. (2017). Export Performance of Pakistan: Role of Structural Factors. State Bank of Pakistan .

[20] Malik, A., \& Majeed, M. T. (2018). Export Performance of Pakistan: Co-Integration Analysis with World Commodity Prices. Pakistan Economic Review , 1 (2), 21-43.

[21] Mubeen, N., \& Ahmad, N. (2016). Towards Measurement and Determinants of Export Diversification: An Empirical Analysis of Pakistan. Pakistan Journal of Commerce and Social Sciences , 588-605.

[22] Nekard, C., \& Ramie, V. (2011). Industry Evidence on the Effects of Government Spending. American Economic Journal: Macroeconomics , 3(1), 36-59.

[23] Quddus, M. A., \& Saeed, I. (2005). An Analysis of Exports and Growth in Pakistan. Pakistan Development Review , 44(4), 921-938.

[24] Rashida, H. (2017). Pakistan and China: Partnership, Prospects and Course Ahead: Policy Perspectives. The Journal of the Institute of Policy Studies , 14(1), 3-22.

[25] Siddiqui, A. H. (2018). Export Diversification and Growth in Pakistan: An Empirical Investigation from 1972 to 2015. Business \& Economic Review, 10 (1), 107-132.

[26] Weiss, J. (2015). Taxonomy of Industrial Policy. United Nation Industrial Development Organization .

[27] WITS. (2018). Economy of Pakistan. Washington D.C, United States of America: World Bank.

[28] Zalk, N. (2014). Industrialization and Industrial Policy. Portfolio Committiee on Trade \& Industry, 1-18. 